\title{
Development of a Protection Model for Teachers as Professional Educators in the Indonesian Legal System
}

\author{
Hasnawi Haris* \\ Departemen of Pancasila and Civic \\ Education \\ Faculty of Social Science \\ Universitas Negeri Makassar \\ Makassar, Indonesia \\ hasnawi.haris@unm.ac.id
}

\author{
Herman \\ Departemen of Pancasila and Civic \\ Education \\ Faculty of Social Science \\ Universitas Negeri Makassar \\ Makassar, Indonesi \\ herman@unm.ac.id
}

\begin{abstract}
The current conditions of teacher protection indicate that the laws and regulations have not been able to protect teachers from the threat of criminal sanctions or neglect of their rights. Therefore, it is necessary to analyze and evaluate laws or regulations on teacher and student protection. This study aimed to find the theoretical constructs of teacher and student protection. It was designed using a qualitative approach to revealing the form of teacher and student protection. The data were collected through documentation and analyzed using a qualitative analysis method followed by a cross-check with people who have expertise in the target field. The analysis model used was the one suggested by Miles and Huberman (2014), consisting of the following stages: (1) data reduction, (2) data display or presentation, and (3) verification and conclusion drawing. The findings suggest that a number of existing regulations have accommodated teacher protection systems. Teacher protection materials cover legal aspects, professional aspects, occupational safety, occupational health and intellectual property rights. Student protection includes protection from violence and discrimination in educational units.
\end{abstract}

\section{Keywords: Professional teachers, Teacher protection, Student protection}

\section{INTRODUCTION}

Teachers are professional educators whose main tasks are to educate, teach, guide, direct, train, assess, and evaluate students in early childhood education through formal education, elementary education, and middle education [1][2][3]. Teacher professionalism will be reflected in the implementation of tasks characterized by expertise, both in material and method. Teaching as a profession is a job or activity that is carried out by someone to earn income; teaching requires expertise, proficiency or skills, and professional education that meet certain quality standards or norms [4][5]. However, teachers are often found confused and being indifferent to their duties as educators because they are afraid of the threat of legal prosecution for violating the child protection law. This happens because many cases have befallen teachers and made them victims.

Many teachers are involved in lawsuits because they have been reported to the police on the pretext of violating the law on child protection and human rights [6][7]. On the accusation of disciplining students, the teachers were prosecuted and imprisoned. Child protection and human rights laws were interpreted excessively after the reformation and were used as weapons by certain parties. For example, in 2014, Abdul Rahim and Muhammad Yusuf, teachers from SMA Negeri 8 Lembang, Pinrang Regency, South Sulawesi, had to deal with law enforcers because they were accused of mistreating their students [3]. Another case was experienced by a teacher at SMAN 1 Kahu, Bone Regency who was reported by his student with allegations of abuse. The same case was experienced by a teacher at SMP Frater Makassar who was arrested after alleged abuse in school [5]. In May 2016, Nurmayani in Bantaeng district was also reported with a similar allegation. There are even cases where teachers are victims of violence, such as what happened to a teacher in Makassar City and a teacher from Sukabumi who was beaten up by student parents.

To ensure the fulfillment of teacher professional duties, the central government, local governments, communities, professional organizations, and/or education units are obliged to provide protection for teachers when carrying out tasks in the field. Teacher protection is a statutory order. Teachers have the right to receive protection in carrying out their duties and protection of intellectual property rights [8][9]. Providing teacher protection is the responsibility of the local government in accordance with its authority .

The current conditions of teacher protection indicate that the laws and regulations have not been able to protect teachers from the threat of criminal sanctions or neglect of their rights. Therefore, it is necessary to analyze and evaluate laws or regulations on teacher and student protection. Legal analysis and evaluation are part of the examination of statutory regulations (executive review), which so far have not been so familiar in constitutional practice compared to the concept of judicial review or legislative review [10]. Analysis and evaluation of laws are aimed at assessing: (1) the extent to which legal norms accommodate the ideological 
values of the state, (2) the objectives that have been achieved by the laws, (3) the effectiveness of the laws, and (4) the gap between expectations and reality after implementing the laws. The results of this evaluation are in the form of recommendations on the status of existing laws and regulations or advice on whether to amend, replace (revoke) or preserve the laws [11].

Legal protection can be defined as all efforts to fulfill rights and provide assistance to give a sense of security to witnesses and/or victims as well as legal protection for crime victims as part of community protection. Legal protection can be realized in various forms, such as through the provision of restitution, compensation, medical services, and legal assistance [12]. Classifies legal protection into two, preventive legal protection and repressive legal protection. Preventive legal protection is an effort to avoid legal disputes, while repressive legal protection is an effort made to resolve disputes [13][14]. In the context of legal protection for teachers, efforts need to be given in both preventive and reformative forms.

This study has urgency, especially in finding the theoretical constructs of teacher and student protection. The significance of this study is to provide a basis for producing regulations regarding teacher and student legal protection in the Indonesian constitutional system. From a theoretical point of view, this study contributes to the development of the theory of teacher and student protection in order to carry out the mandate of the law on teachers and lecturers as well as government regulations on teachers. In practical terms, the findings of this study can provide DPR, Provincial DPRD, Regency/City DPRD, regents/mayors with fruitful insights into formulating policies related to the legal protection of the teaching profession.

\section{METHOD}

The current study aimed to reveal the form of teacher and student protection. It was designed using a qualitative approach that included the following steps; (1) identify and select research problems, (2) establish focus and sub-focus, (3) establish data collection procedures and techniques and perform data collection, (5) manage the collected data, (6) analyze inductively to generalize, and (7) draw conclusions from the findings. The data were collected through documentation and analyzed using a qualitative analysis method followed by a cross-check with people who have expertise in the target field. The analysis model used was the one suggested by, consisting of the following stages: (1) data reduction, (2) data display or presentation, and (3) verification and conclusion drawing[15][16].

\section{RESULTS AND DISCUSSION}

\section{A. Teacher Protection in the Indonesian Legal System}

In particular, various laws and regulations that serve as a juridical basis for teacher and student protection have been produced. These legal products include laws and government regulations. Law Number 20 of 2003 concerning the National Education System Article 40 stipulates that educators and education personnel are entitled to (1) adequate income and social welfare security, (2) awards in accordance with work duties and performance, (3) career development in accordance with the demands of quality development, and (4) legal protection in carrying out duties and rights to intellectual property; and (5) opportunities to use educational facilities, infrastructure and facilities to support the effortless execution of tasks.

Article 14 which regulates the rights and obligations of teachers, it is stated that in carrying out professional duties, teachers have the right to (1) earn income above the minimum necessity of life and receive social welfare security, (2) get promotions and awards in accordance with work duties and performance, (3) get protection in carrying out tasks and intellectual property rights, (4) get opportunities to improve competencies, (5) obtain and utilize learning facilities and infrastructure to support professionalism, (6) have the freedom to provide assessments and participate in determining graduation, awards, and/or sanctions for students in accordance with educational principles, teacher code of ethics, and laws and regulations, and (7) obtain a sense of security and guarantee of safety in carrying out their duties [17][18].

In fact, Article 39 of the law states that the government, local governments, communities, professional organizations and/or education units are obliged to provide protection for teachers in carrying out their duties. Protection referred to includes legal protection, professional protection, and protection of occupational safety and health. Legal protection includes protection against acts of violence, threats, discriminatory treatment, intimidation or unfair treatment from students, parents of students, society, the bureaucracy, or other parties. Professional protection includes protection against termination of employment that is not in accordance with statutory regulations, improper remuneration, restrictions on the expression of views, harassment of the profession, and other restrictions/violations that can hinder teachers from carrying out their duties. Protection of occupational safety and health includes protection against risks of occupational safety disturbances, work accidents, fires during work, natural disasters, work environment health, and/or other related risks.

The legal standing of teacher protection is also given specifically to professional organizations that have the authority to provide protection. Furthermore, Article 42 of the law states that teacher professional organizations have the authority to establish and enforce teacher codes of ethics, provide legal assistance to teachers, provide protection for the teaching profession, and carry out teacher professional training and development.

Teacher/educator protection is substantially regulated in various articles which include legal protection, professional protection, occupational safety and health protection, and protection of teacher's intellectual property [19]. The protection of teacher's intellectual property is provided in the form of protection of copyright and/or industrial property rights of teachers.

Restrictively defines the freedom of teachers in imposing sanctions on students. As stipulated in Article 39, teachers have the freedom to impose sanctions on students who violate religious norms, moral norms, norms of decency, 
written and unwritten regulations set by the teachers, regulations at the level of educational units, and laws and regulations in the learning process that is in under their authority [20]. The legal product provides space for teachers to carry out their duties professionally without feeling pressured. Article 40 (1) states that teachers have the right to receive protection in carrying out their duties in the form of a sense of security and safety guarantees from the government, local governments, educational units, teacher professional organizations, and/or the community.

Based on the explanation of evaluation and analysis of the substance and vertical and horizontal harmonization of related laws and regulations that have been mentioned above, the existence of teacher protection in order to improve the quality and accountability of education must be ensured. Analysis of legal aspects for teacher protection is part of the efforts to protect teachers in carrying out their professional duties comfortably and safely. A number of existing regulations have accommodated the teacher protection system, including the constitution, laws, government regulations and lower regulations made by the government. The application of teacher protection regulations involves agencies at the central government level, such as the Ministry of Education and Culture, the Ministry of Home Affairs, the Ministry of Religion, the Ministry of Law, the Indonesian Police and other relevant ministries. Likewise, the offices in the regions such as the education office, population service, manpower office and so on have been involved in the formulation of these regulations. In addition, the implementation of regulations is also carried out by professional institutions such as the Indonesian Teachers Association (PGRI) so that de facto it can be said that the government has provided legal protection to teachers in Indonesia.

Laws and regulations related to teacher protection should be obeyed and implemented effectively because their legal authority and strength have been comprehensively regulated. Basically, professional protection is a necessity for teachers in carrying out their duties. The power of laws for teacher protection has also been regulated in statutory regulations. It should also be noted that regarding teacher protection, Law Number 14 of 2005 requires a Regulation of the Minister of Education and Culture, as a technical explanation for its application [21].

\section{B. Student Protection in the Indonesian Legal System}

Student protection has been regulated in which substantively regulates children's rights. Although legal instruments are owned, the execution of Law Number 23 of 2002 concerning Child Protection has not been run effectively due to overlaps between statutory regulations related to the definition of children. On this basis, Law Number 35 of 2014 was formed, in which there are several amendments to Law Number 23 of 2002 . However, based on the results of analysis and evaluation, it has been found that several regulations have not been conducted effectively. One of them is the lack of facilities that support the protection and welfare of children [22].

Student protection under this law is classified into child protection. The general provisions of Article 1 paragraph (2) of [defines child protection as all activities that guarantee and protect children and their rights to live, grow, develop and participate optimally according to their dignity, human dignity, and to receive protection against violence and discrimination [23]. Through this legal product, child protection aims to ensure the fulfillment of children's rights so that they can live, grow, develop and participate optimally in accordance with human dignity as well as obtain protection against violence and discrimination, for the realization of prosperous Indonesian children who have good quality and noble character.

Specifically, children's rights and responsibilities have also been regulated in Article 16 which states that (1) every child has the right to receive protection from being subjected to torture or the imposition of inhuman punishment, (2) every child has the right to obtain freedom in accordance with the law, (3) arrest, detention, or imprisonment of children is only carried out if it is in accordance with the applicable law and can only be done as a last resort.

The importance of child protection is clearly indicated in the rights and responsibilities section of Article 20 which states that the state, government, community, family, and parents are obliged and responsible for the implementation of child protection. Even at the institutional level, state and government entities are obliged and responsible for providing protection for children, as Article 21 stipulates that the state and government are obliged and responsible to respect and guarantee children's rights regardless of the ethnicity, religion, race, class, gender, culture and language of the children, legal status of the children, order of birth of the children, and physical and/or mental condition of the children. Likewise, the same content is regulated in Article 22 which states that the state and government are obliged and responsible to provide facilities and infrastructure to support the implementation of child protection.

\section{CONCLUSION}

Teacher and student protection in the Indonesian legal system is realized through the implementation of the provisions of Law Number 23 of 2003 concerning the National Education System, Law Number 14 of 2005 concerning Teachers and Lecturers, Government Regulation Number 74 of 2008 concerning Teachers, Regulation of the Minister of Education and Culture of the Republic of Indonesia Number 10 of 2017 concerning Protection of Educators and Education Personnel. Student protection is regulated in Law Number 23 of 2002 concerning Child Protection and Law Number 35 of 2014 concerning Amendments to Law Number 23 of 2002 concerning Child Protection. Teacher protection covers various aspects, including legal protection, professional protection, protection of teacher occupational safety and health and protection of teacher intellectual property rights. Student protection includes protection against violence and discrimination in educational units.

\section{ACKNOWLEDGMENT}

Thank you very much to the Chancellor of the Universitas Negeri Makassar who have provided funding and opportunities for us to conduct research. 


\section{REFERENCES}

[1] M. R. Lavery, J. Nutta, and A. Youngblood, "Analyzing student learning gains to evaluate differentiated teacher preparation for fostering English learners' achievement in linguistically diverse classrooms," J. Teach. Educ., vol. 70, no. 4, pp. 372-387, 2019.

[2] D. Sofyan, E. Boerieswati, and M. Asmawi, "Ability to Teach Indonesian Language in Elementary schools: Comparative Study of Teachers who have taken Professional Education and have not Participated in Professional Teacher Education," Int. J. Multicult. Multireligious Underst., vol. 6, no. 6, pp. 781-787, 2020.

[3] D. Mitchell and D. Sutherland, What really works in special and inclusive education: Using evidencebased teaching strategies. Routledge, 2020.

[4] A. Purwantiningsih and P. Suharso, "Improving Teacher Professionalism Toward Education Quality in Digital Era," in Journal of Physics: Conference Series, 2019, vol. 1254, no. 1, p. 12019.

[5] M. Said and H. Haris, "Development of Character Education-Based Learning Devices in Local History Subject," in International Conference on Social Science 2019 (ICSS 2019), 2019.

[6] A. Maloku and E. Maloku, "Protection of Human Trafficking Victims and Functionalization of Institutional Mechanisms in Kosovo," Acta Univ. Danubius. Juridica, vol. 16, no. 1, 2020.

[7] J. Donnelly and D. J. Whelan, International human rights. Routledge, 2020.

[8] A. G. Barabashev, D. V Ponomareva, and J. A. Burt, "Review of the Results of Scientific Activities: Protecting Intellectual Property in Russian and American Legal Practice," in Journal of Physics: Conference Series, 2019, vol. 1406, no. 1, p. 12009.

[9] H. de Souza Andrade and L. M. S. Urbina, "The Intellectual Property Protection and Commercialization Management Process in a Technology Licensing Office," Int. J. Adv. Eng. Res. Sci., vol. 6, no. 12, 2019.

[10] F. Bothma and J. P. Rossouw, "The accountability and professional security of the South African higher education lecturer," South African J. High. Educ., vol. 33, no. 2, pp. 29-51, 2019.

[11] O. Koubrak, D. L. VanderZwaag, and B. Worm, "Saving the North Atlantic right whale in a changing ocean: Gauging scientific and law and policy responses," Ocean Coast. Manag., p. 105109, 2020.

[12] A. Syahrin and M. Din, "Criminal Policy Concerning Restitution and Its Implementation for Victims of Sexual Violence in Aceh," in International Conference on Law, Governance and Islamic Society (ICOLGIS 2019), 2020, pp. 140-144.

[13] S. Zulaikha, K. Rofiah, and R. S. Pertiwi, "Legal Protection of Lenders in the Implementation of Financial Technology Based on Peer to Peer Lending," KnE Soc. Sci., pp. 1305-1316, 2019.

[14] S. Laurensius, D. Situngkir, R. Putri, and R. Fauzi, "Cyber Bullying Against Children In Indonesia," in International Conference on Social Sciences, Humanities, Economics and Law, 2018.

[15] H. Wijaya, Analisis Data Kualitatif: Sebuah Tinjauan Teori \& Praktik. Sekolah Tinggi Theologia Jaffray, 2019.

[16] M. B. Miles, A. M. Huberman, and J. Saldana, Qualitative Data Analysis: A Method Sourcebook. New York: Routledge, 2014.

[17] W. Wermke and E. Forsberg, "The changing nature of autonomy: Transformations of the late Swedish teaching profession," Scand. J. Educ. Res., vol. 61, no. 2, pp. 155-168, 2017.

[18] V. B. Gómez-Pablos, M. M. del Pozo, and A. G.-V. Muñoz-Repiso, "Project-based learning (PBL) through the incorporation of digital technologies: An evaluation based on the experience of serving teachers," Comput. Human Behav., vol. 68, pp. 501$512,2017$.

[19] D. L. Kgosimore, "Educators as victims of workplace violence in selected secondary schools in the Capricorn District of the Limpopo Province, South Africa." University of Limpopo, 2018.

[20] E. Kreytchova and N. Stalyanova, "The power of public speech." Sofia: Paradigma, 2017.

[21] S. N. Jayakusuma, S. Sarumpaet, and F. G. Dewi, "The Perception Of Civil Servants In Higher Education To Remuneration System, And Its Effect On Motivation And Performance," Int. J. Sci. Technol. Res., vol. 7, no. 9, pp. 129-137, 2018.

[22] F. Casal Bértoa and D. Taleski, "Regulating party politics in the Western Balkans: The legal sources of party system development in Macedonia," Democratization, vol. 23, no. 3, pp. 545-567, 2016.

[23] I. G. A. K. P. Sari, "Legal Protection For Children As Performance Of Criminal Action," Ganesha Law Rev., vol. 2, no. 1, pp. 26-36, 2020. 